\title{
ARHGEF7 Gene
}

National Cancer Institute

\section{Source}

National Cancer Institute. ARHGEF7 Gene. NCI Thesaurus. Code C97199.

This gene plays a role in apoptosis and GT Pase-mediated signaling. 